\title{
Enhancement of waste activated sludge dewaterability using calcium peroxide pre-oxidation and chemical re-flocculation
}

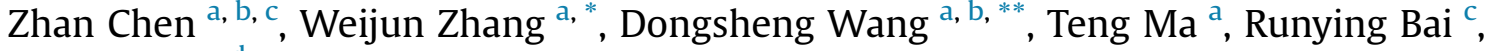 \\ Dezhong $\mathrm{Yu}^{\mathrm{d}}$ \\ a School of Environmental Studies, China University of Geosciences, Wuhan 430074, Hubei, China \\ ${ }^{\mathrm{b}}$ State Key Laboratory of Environmental Aquatic Chemistry, Research Center for Eco-Environmental Sciences, Chinese Academy of Sciences, Beijing 100085, \\ China \\ c School of Civil Engineering, Inner Mongolia University of Technology, Hohhot 010051, China \\ ${ }^{\mathrm{d}}$ School of Chemistry and Environmental Engineering, Wuhan Institute of Technology, 430073 Hubei, China
}

\section{A R T I C L E I N F O}

\section{Article history:}

Received 4 April 2016

Received in revised form

6 July 2016

Accepted 10 July 2016

Available online 16 July 2016

\section{Keywords:}

Calcium peroxide pre-oxidation

Chemical flocculation

Dewatering behavior

Extracellular polymeric substances

Waste activated sludge

\begin{abstract}
A B S T R A C T
The effects of combined calcium peroxide $\left(\mathrm{CaO}_{2}\right)$ oxidation with chemical re-flocculation on dewatering performance and physicochemical properties of waste activated sludge was investigated in this study. The evolutions of extracellular polymeric substances (EPS) distribution, composition and morphological properties were analyzed to unravel the sludge conditioning mechanism. It was found that sludge filtration performance was enhanced by calcium peroxide oxidation with the optimal dosage of $20 \mathrm{mg} /$ gTSS. However, this enhancement was not observed at lower dosages due to the absence of oxidation and the performance deteriorated at higher dosages because of the release of excess EPS, mainly as proteinlike substances. The variation in soluble EPS (SEPS) component can be fitted well with pseudo-zero-order kinetic model under $\mathrm{CaO}_{2}$ treatment. At the same time, extractable EPS content (SEPS and loosely bound EPS (LB-EPS)) were dramatically increased, indicating sludge flocs were effectively broken and their structure became looser after $\mathrm{CaO}_{2}$ addition. The sludge floc structure was reconstructed and sludge dewaterability was significantly enhanced using chemical re-flocculation (polyaluminium chloride $(\mathrm{PACl})$, ferric iron $\left(\mathrm{FeCl}_{3}\right)$ and polyacrylamide (PAM)). The inorganic coagulants performed better in improving sludge filtration dewatering performance and reducing cake moisture content than organic polymer, since they could act as skeleton builders and decrease the sludge compressibility.
\end{abstract}

() 2016 Elsevier Ltd. All rights reserved.

\section{Introduction}

Due to the improvement and popularization of municipal wastewater treatment, sludge production was dramatically increased in recent decades (Kim et al., 2002). It will pose a significant threat to the ecological system without effectively treatment and disposal (Wei et al., 2003). Wastewater treatment plant (WWTP) disposal of excess sludge with traditional treatment are quite expensive, which accounts for up to $60 \%$ of the total operation

\footnotetext{
* Corresponding author. School of Environmental Studies, China University of Geosciences, Wuhan 430074, Hubei, China.

** Corresponding author. State Key Laboratory of Environmental Aquatic Chemistry, Research Center for Eco-Environmental Sciences, Chinese Academy of Sciences, Beijing 100085, China.

E-mail addresses: zhwj_1986@126.com (W. Zhang), wgds@rcees.ac.cn (D. Wang).
}

(Low et al., 2000). In addition, treatment and disposal of waste sludge is also faced with many technical problems and challenges. Waste activated sludge from secondary settling tank generally contains over $99 \mathrm{wt} \%$ water. Especially, sludge with high moisture content may result in the issues of great bulk, expensive cost and difficult for transportation. Therefore, the development of high performance dewatering processes has been one of the most important research areas in current China. In general, the moisture in sludge system can be classified into free water (accounted for about $70 \mathrm{wt} \%$ ), interstitial water (about $20 \mathrm{wt} \%$ ), adsorbed water (about $7 \mathrm{wt} \%$ ) and bound water (about $3 \mathrm{wt} \%$ ) (Vaxelaire and Cezac, 2004). Except for sludge properties, the dewatering performance was mainly dependent on selection of sludge devices and chemical conditioning methods (Beauchesne et al., 2007).

Extracellular polymeric substances (EPS) account for about $60-80 \%$ of total sludge mass (Liu and Fang, 2002) and significantly affect other sludge physicochemical properties, such as surface 
charge, floc stability and rheological behavior (Mikkelsen and Keiding, 2002). Many previous studies have demonstrated that EPS was the most crucial deciding factor for sludge dewatering (Mikkelsen and Keiding, 2002; Niu et al., 2013; Chen et al., 2015). Houghton et al. (2001) reported that the dewaterability was determined by the contents of EPS and there existed an optimal EPS content for each sludge, at this time, the sludge exhibited the best dewatering property. Many researchers found that proteins and polysaccharides ratios had more significant effect on sludge dewatering property (Higgins and Novak, 1997a). Murthy and Novak (1999) suggested that high proteins/polysaccharide ratio was detrimental for sludge dewatering performance. Recent years, EPS was found to have double layers including the loosely bound EPS (LB-EPS) which is diffused from the tightly bound EPS (TB-EPS) that surrounds the cells (Li and Yang, 2007; Poxon and Darby, 1997; Ramesh et al., 2006). Moreover, some researchers reported that only the LB-EPS was related to the sludge dewaterability ( $\mathrm{Li}$ and Yang, 2007; Ramesh et al., 2006; Raynaud et al., 2012). Yu et al. (2008) suggested that sludge floc was composed by five fractions: supernatant, slime, LB-EPS, TBEPS, and pellet, and the sludge dewatering performance was mainly influenced by soluble EPS characteristics.

Generally speaking, it is essential to precondition the sludge particles with chemicals properly before the dewatering in order to improve the operating performance of devices. For example, addition of inorganic or organic flocculants can agglomerate fine sludge colloids to form large flocs through charge neutralization and bridging, which can be more easily separated from the water (Niu et al., 2013; Zhang et al., 2014). EPS fraction in activated sludge was highly hydrated, and the traditional chemical flocculants was ineffective to destroy EPS structure and convert bound water into free water (Neyens et al., 2004). Therefore, the advanced sludge technologies (AST) were developed to improve sludge dewatering property and cake solid content by solubilizing EPS components. The established AST includes photo-Fenton/Fenton oxidation technology (Liu et al., 2013; Neyens and Baeyens, 2003; Tokumura et al., 2007), thermal hydrolysis, acid and alkali treatment (Zhu et al., 2013), heat treatment (Neyens et al., 2004), enzymatic treatment (Chen et al., 2015; Thomas et al., 1993) and integrated processes.

Calcium peroxide $\left(\mathrm{CaO}_{2}\right)$ is one of the most traditional and safest solid inorganic peroxy compounds which can be considered a "solid form" of $\mathrm{H}_{2} \mathrm{O}_{2}$ (Qian et al., 2013). $\mathrm{CaO}_{2}$ dissolved in water may generate $\mathrm{O}_{2}$ and $\mathrm{H}_{2} \mathrm{O}_{2}$ which is known to be a strong oxidant; calcium ions generated at the same time could act as coagulants (Higgins and Novak, 1997b). Besides its stable oxidation capability, $\mathrm{CaO}_{2}$ also possesses the capacities of bleaching, disinfection, and deodorizing. Hence, $\mathrm{CaO}_{2}$ has been widely used in agriculture, aquiculture, and medicine ( $\mathrm{Ma}$ et al., 2007). $\mathrm{CaO}_{2}$ can be used to promote organic pollutant degradation in contaminated soil due to its oxidation (Ndjou'ou and Cassidy, 2006). According to Zhang et al. (2015a), $\mathrm{CaO}_{2}$ was very effective in sludge solubilization and removal of endocrine disrupting compounds (EDCs). In addition, $\mathrm{CaO}_{2}$ can be also function as an alkali to improve the sludge hydrolysis due to formation of $\mathrm{Ca}(\mathrm{OH})_{2}$ (Wu et al., 2010; Zhu et al., 2013).

As mentioned above, the sludge dewatering is one of the critical steps toward sludge treatment, whilst it would finally make significant influence on sludge reduction and disposal. EPS fraction was highly hydrated, $\mathrm{CaO}_{2}$ oxidation was able to solubilize sludge EPS and result in release of water binding to them. Then, the chemical flocculation could be used to agglomerate sludge tiny flocs and improve sludge filterability. However, few of previous studies have investigated the feasibility of combined $\mathrm{CaO}_{2}$ treatment and chemical re-flocculation on dewatering performance.
Especially, the evolution of EPS and morphological properties under chemical conditioning was still not clear. Thus, the objectives of this study were to: (a) investigate the effect of combined $\mathrm{CaO}_{2}$ preoxidation and chemical re-flocculation on sludge dewatering performance and optimize the process combination modes and dosage of sludge conditioners; (b) get insights into the kinetic variation in distribution and composition of EPS under $\mathrm{CaO}_{2}$ hydrolysis reaction; (c) unravel the mechanism and clear the enhancement of activated sludge dewatering performance by analyzing the EPS and morphological properties under treatment by $\mathrm{CaO}_{2}$ in combination with re-flocculation process.

\section{Materials and methods}

\subsection{Waste sludge and reagents}

Waste activated sludge was obtained from the Beixiaohe WWTP in Beijing city. This WWTP treats approximately 1,000,000 $\mathrm{m}^{3}$ daily by combined membrane bioreactor (MBR) and ozonation process. The raw sludge characteristics were given in Table 1, which can be used as baseline background reading.

All the reagents were analytical reagents (AR) except for calcium peroxide (Chemically Pure, $\mathrm{CP}$ ), polyaluminium chloride $(\mathrm{PACl})$ and polyacrylamide (PAM). All of reagents were purchased from Sinopharm Chemical Reagent Co., Ltd in China except for PACl and PAM. The concentration of self-made ferric iron $\left(\mathrm{FeCl}_{3}\right)$ and $\mathrm{PACl}$ solution were $100 \mathrm{~g} / \mathrm{L}$.

\subsection{Batch test}

\subsection{1. $\mathrm{CaO}_{2}$ hydrolysis test}

An aliquot of $150 \mathrm{~mL}$ of sludge was placed into Erlenmeyer flasks with different dosages of $\mathrm{CaO}_{2}$. Then the flasks were put into a horizontal oscillator $\left(25 \pm 1^{\circ} \mathrm{C}\right)$ at the speed of $200 \mathrm{rpm} / \mathrm{min}$ for $1 \mathrm{~h}$. The following procedures at the end of this test were the measurement of specific resistance to filtration (SRF) and EPS extraction and analysis.

With regard to the kinetic test, $800 \mathrm{~mL}$ of sludge was placed into $1 \mathrm{~L}$ beaker with mixing by using cantilever-type stirrer after $\mathrm{CaO}_{2}$ addition of $100 \mathrm{mg} / \mathrm{gTSS}$. Meanwhile, $50 \mathrm{~mL}$ of sludge samples were taken out and placed into centrifuge tubes at different time intervals within $120 \mathrm{~min}$. The samples were promptly centrifuged and filtered by membrane of $0.45 \mu \mathrm{m}$ so as to stop the reaction in tubes.

\subsubsection{Chemical re-flocculation}

Sludge samples of $100 \mathrm{~mL}$ were used in the experiments. The following mixing procedure was used: a rapid mix period for $30 \mathrm{~s}$ at $200 \mathrm{rpm} / \mathrm{min}$ followed by a slow-stir phase at $50 \mathrm{rpm} / \mathrm{min}$ for $10 \mathrm{~min}$. The coagulants ( $\mathrm{PACl}, \mathrm{FeCl}_{3}$ or PAM) were added with agitation using a graduated finnpipette. At the end of mixing, the conditioned sludge was allowed to settle in the beaker for $30 \mathrm{~min}$. Finally, the floc morphology and characteristics of soluble EPS were determined as the measurements expanded upon in following sections.

\subsubsection{Determination of sludge dewaterability}

SRF represents the resistance of unit mass of sludge in unit filtration area under a certain pressure, it has the similar physical process to the pressure filtration dewatering. The SRF was conducted in a $100 \mathrm{~mL}$ Buchner funnel using a quantitative filter paper (see Fig. S1 of supporting information (SI)). The Buchner funnel was filled with $50 \mathrm{~mL}$ of sludge suspension, and a constant pressure of $60 \mathrm{kPa}$ was applied by a vacuum pump. The volume of filtrate under pressure was continuously recorded every $2 \mathrm{~s}$ by METTLER TOLEDO 
Table 1

Characteristics of sludge obtained from Beixiaohe WWTP.

\begin{tabular}{|c|c|c|c|c|c|c|c|}
\hline Indicator & Moisture content (wt\%) & $\mathrm{pH}$ & VSS/TSS & $\mathrm{SRF}(\mathrm{m} / \mathrm{kg})$ & $\mathrm{d}_{0.5}(\mu \mathrm{m})$ & Zeta potential $^{\star}(\mathrm{mV})$ & $\mathrm{SCOD}(\mathrm{mg} / \mathrm{L})$ \\
\hline Value & 98.3 & 6.81 & 0.78 & $1.53 \times 10^{13}$ & 58.68 & -14.3 & 132 \\
\hline
\end{tabular}

*Samples for zeta potential were diluted by 10 times.

balance connected with computer and it stopped after $10 \mathrm{~min}$. The SRF of the sludge was calculated by:

$S R F=\frac{2 P A^{2} b}{\mu \omega}$

Where $P\left(\mathrm{~kg} / \mathrm{m}^{2}\right)$ is the pressure applied, $A\left(\mathrm{~m}^{2}\right)$ is the filter area, $\mu\left(\mathrm{kg} \cdot \mathrm{s} / \mathrm{m}^{2}\right)$ is the kinetic viscosity $(\mathrm{KV}), \omega\left(\mathrm{kg} / \mathrm{m}^{3}\right)$ denotes dry solid weight per unit volume sludge on the filtrate media, $b$ is the timeto-filtration ratio, which is the slope of the curve that is obtained by plotting the ratio of the time of filtration to the volume of filtrate $(t)$ $V)$ versus the filtrate volume $(V)$.

\subsection{Analytical methods}

\subsubsection{Floc morphology}

Sludge floc size and fractal dimension $\left(\mathrm{D}_{\mathrm{F}}\right)$ were measured by Malvern Mastersizer 2000 (UK) with stirrer speed of $300 \mathrm{rpm} / \mathrm{min}$. Each sample was determined three times with its measuring time of $10 \mathrm{~s}$. Light scattering method has been widely used for the determination of aggregate mass fractal dimension (Wei et al., 2009). The technique involves measurement of light intensity $I$ as a functions of the scatter vector $Q$.

For independently scattering aggregates, the relationship among $I, Q$ and the fractal dimension $D_{F}$ can be represented by Eq. (2):

$I \propto Q^{D_{F}}$

The relationship shown in Eq. (2) indicates the determination of $D_{F}$, which can be given by the slope of $\log I$ versus $\log Q$ by fitting a straight line.

\subsubsection{Extraction and analysis of EPS}

2.3.2.1. EPS extraction. A heat extraction method was modified to extract the LB-EPS and TB-EPS from the sludge (Niu et al., 2013). A sludge suspension was firstly dewatered by centrifugation in a $50 \mathrm{~mL}$ tube at $3000 \mathrm{~g}$ for $10 \mathrm{~min}$. The supernatant was collected as SEPS. The sludge pellet in the tube was then resuspended into $15 \mathrm{~mL}$ of $0.05 \% \mathrm{NaCl}$, sonicated at $20 \mathrm{kHz}$ for $2 \mathrm{~min}$, shaken horizontally at $150 \mathrm{rpm} / \mathrm{min}$ for $10 \mathrm{~min}$ and sonicated again for an additional $2 \mathrm{~min}$. The liquor was centrifuged at $8000 \mathrm{~g}$ for $10 \mathrm{~min}$ to separate solids and supernatant. The collected supernatant was regarded as the LB-EPS. The residual sludge pellet left in the centrifuge tube was resuspended in a $0.05 \% \mathrm{NaCl}$ solution, sonicated for $3 \mathrm{~min}$, then heated at $60{ }^{\circ} \mathrm{C}$ for $30 \mathrm{~min}$, finally centrifuged at $12,000 \mathrm{~g}$ for $20 \mathrm{~min}$ to collect TB-EPS.

\subsubsection{Chemical composition analysis of EPS}

2.3.2.2.1. Three-dimensional excitation emission matrix (3DEEM). It was reported that 3-DEEM analytic technique has been widely used in characterization of natural organic matters in water body and has the advantages of high sensitivity and accuracy (Henderson et al., 2009). 3-DEEM was measured by a Hitachi F4500 fluorescence spectrophotometer with an excitation range from 200 to $400 \mathrm{~nm}$ and an emission range from 220 to $550 \mathrm{~nm}$. The spectra were recorded at a scan rate of $12,000 \mathrm{~nm} / \mathrm{min}$, using excitation and emission slit bandwidths of $5 \mathrm{~nm}$. The EPS samples were diluted by different times noted in figures.

2.3.2.2.2. High-performance size exclusion chromatography (HPSEC). Molecular weight (MW) was determined by a Waters liquid chromatography system that consisted of a Waters 2487 Dual $\lambda$ Absorbance Detector, Waters 1525 pump system. A Shodex KW 802.5 gel chromatography column (Shoko, Japan) was used for organic materials separation. The mobile phase buffered with $5 \mathrm{mM}$ phosphate to $\mathrm{pH} 6.8$, and $0.01 \mathrm{M} \mathrm{NaCl}$, was filtered through a $0.22 \mu \mathrm{m}$ membrane, and then degassed for 30 min by means of ultra-sonication before use. A $200 \mu \mathrm{L}$ sample was injected at a flow rate of $0.8 \mathrm{~mL} / \mathrm{min}$. Polystyrene sulfonate standards (Sigma-Aldrich, USA) of MWs 1.8-32 kDa were used for apparent molecular weight (AMW) (Chow et al., 2008; Wang et al., 2010).

2.3.2.3. Field emission scanning electron microscope (FE-SEM) and fourier transform infrared (FTIR) analysis. The sludge samples were made by freeze-drying treatment under vacuum at $-60^{\circ} \mathrm{C}$ for $72 \mathrm{~h}$, which were analyzed by FTIR NICOLET 8700 spectrometer to identify various functional groups in the EPS samples. All the spectra were in a scanning range from 500 to $4000 \mathrm{~cm}^{-1}$. With samples freeze-dried, FE-SEM analysis was used by HITACHI SU8020 FE-SEM.

\subsubsection{Other indicators}

Dissolved organic carbon (DOC) was determined by using Total Organic Carbon Analyzer (TOC-L, SHIMADZU Inc., Japan). Concentrations of metal ions were measured with inductively coupled plasma optical emission spectrometer (ICP-OES). Other sludge parameters, including total suspended solid (TSS), volatile suspended solids (VSS) were determined according to standard methods (APHA, 1998). pH was measured by a pHS-3C (Shanghai, China) $\mathrm{pH}$ meter.

Each treatment sample was analyzed in triplicate and the relative deviations of all analyses were always less than $5 \%$.

\section{Results and discussion}

\subsection{Effects of $\mathrm{CaO}_{2}$ treatment on sludge dewaterability}

Fig. 1 (a) showed that with the increase of $\mathrm{CaO}_{2}$ addition, SRF initially decreased before passing through a minimum at a dosage of $20 \mathrm{mg} / \mathrm{g}$ TSS and then increased at higher dosages. Meanwhile, the evolution of cake moisture content had the same tendency. It reached the minimum of $86.31 \mathrm{wt} \%$ when the dosage of $\mathrm{CaO}_{2}$ was $20 \mathrm{mg} / \mathrm{gTSS}$ and the SRF was $1.28 \times 10^{13} \mathrm{~m} / \mathrm{kg}$. According to the value of SRF, sludge can be classified into poor dewaterability $\left(>1 \times 10^{13} \mathrm{~m} / \mathrm{kg}\right)$, medium dewaterability, $\left(0.5-0.9 \times 10^{13} \mathrm{~m} / \mathrm{kg}\right)$ and good dewaterability $\left(<0.4 \times 10^{13} \mathrm{~m} / \mathrm{kg}\right.$ ) (Zhang et al., 2014). By comparison, although addition of $\mathrm{CaO}_{2}$ can improve sludge dewatering performance, the minimum SRF value can not reach the sludge with good dewaterability. Thus, a link to the chemical reflocculation work is required at this point. 

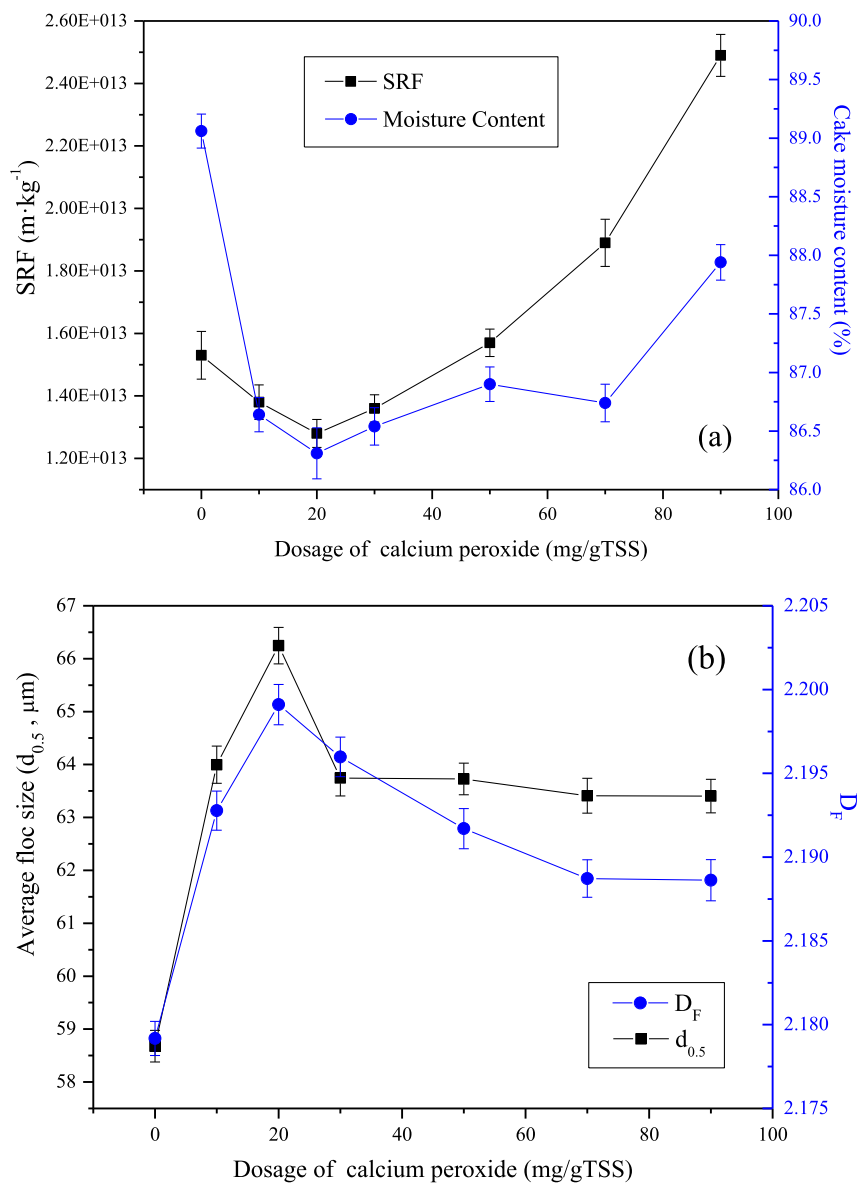

Fig. 1. Effects of $\mathrm{CaO}_{2}$ dosage on sludge: (a) dewatering performance; (b) floc morphological properties.

\subsection{Effects of $\mathrm{CaO}_{2}$ dosage on physicochemical properties of waste sludge}

\subsubsection{Effects of $\mathrm{CaO}_{2}$ dosage on sludge floc morphological properties}

As depicted in Fig. 1 (b), for average sludge floc size $\left(\mathrm{d}_{0.5}, \mu \mathrm{m}\right)$, with the increase of $\mathrm{CaO}_{2}$ addition, there was a sharp increase. It reached the maximum of $66.25 \mu \mathrm{m}$ when the dosage of $\mathrm{CaO}_{2}$ was $20 \mathrm{mg} / \mathrm{gTSS}$. After $\mathrm{CaO}_{2}$ dosage was further increased to above $30 \mathrm{mg} / \mathrm{gTSS}$, the pattern approached to a flat. As a matter of fact, calcium peroxide had double effects on oxidation and flocculation. Due to the combinative effects of calcium ions coagulation and oxidative lysis of EPS in $\mathrm{CaO}_{2}$ treatment, sludge flocs initially agglomerated into larger ones under charge neutralization (Higgins and Novak, 1997b). Since the solubilization of sludge flocs was gradually enhanced with $\mathrm{CaO}_{2}$ oxidation at higher dosages, so that the average floc size then decreased.

Generally, the higher the $D_{F}$ always means the more irregular surface of the sludge. A floc with a $D_{F}$ close to 3 indicates a close interior packing, and an extremely loose packing feature appears at a $D_{F}$ close to 1 (Hung et al., 1996). Eriksson and Alm found that higher charge-density coagulants interact strongly with negatively charged surfaces, and thus it would have a flat adsorption conformation. Therefore, the flocculated particles will come in close contact with each other, which gives a strong binding and reduces the possibility of movement of the particles relative each other (Eriksson and Alm, 1993). The change of $\mathrm{D}_{\mathrm{F}}$ can be seen in Fig. 1 (b). Generally, it rose firstly and then fell with the increase of $\mathrm{CaO}_{2}$ addition. When dosage of $\mathrm{CaO}_{2}$ was $20 \mathrm{mg} / \mathrm{gTSS}$, the sludge floc average size and density reached the maximum due to the double effects of $\mathrm{CaO}_{2}$, meanwhile the sludge SRF reached the minimum as previously mentioned. Therefore, the sludge filtration dewatering performance was enhanced by using calcium peroxide preoxidation at optimal dosage.

\subsubsection{Effects of $\mathrm{CaO}_{2}$ dosage on EPS distribution and composition}

As depicted in Fig. 2 (a), with the increase of $\mathrm{CaO}_{2}$ addition,
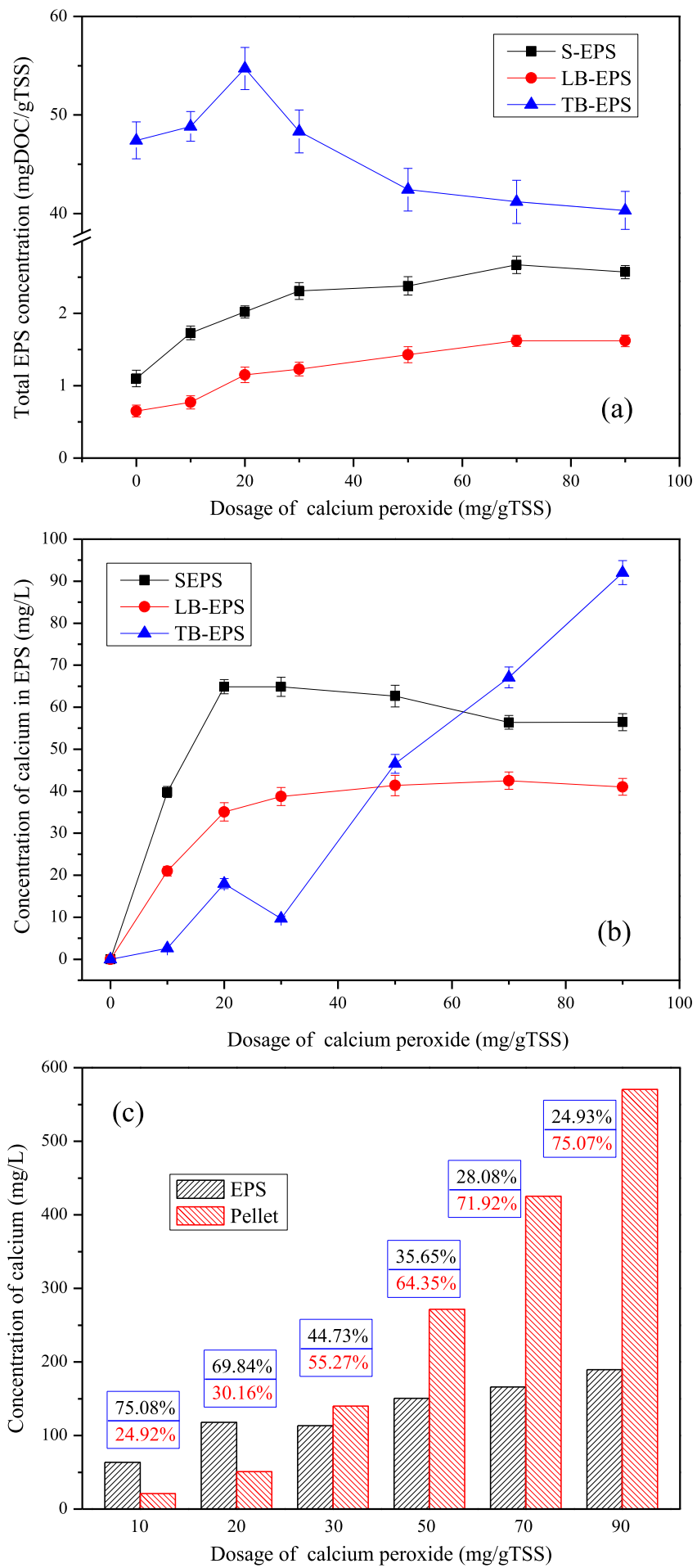

Fig. 2. Effect of $\mathrm{CaO}_{2}$ dosage on EPS distribution and composition: (a) EPS concentration; (b) Calcium distribution in EPS; (c) Total calcium distribution. 
sludge SEPS and LB-EPS components significantly increased from 1.10 to $0.65 \mathrm{mgDOC} / \mathrm{gTSS}$ to 2.57 and $1.62 \mathrm{mgDOC} / \mathrm{gTSS}$ respectively. However, TB-EPS components decreased from 47.42 to 40.32 mgDOC/gTSS but goes through a maximum of $54.72 \mathrm{mgDOC} / \mathrm{gTSS}$. According to our previous study, the solubilization of organic matters by sludge floc lysis with oxidation of peroxides may lead to the gradual transformation from TB-EPS to LB-EPS then to SEPS. Furthermore, it was reported that the high molecular weight biopolymer in SEPS had a more crucial influence on sludge filtration properties (Lyko et al., 2008). Raynaud et al. (2012) suggested that a sludge with poor filterability is usually related to such flocs with a loose packing, less fine particle retention and a more compressible cake structure. Therefore, sludge filtration performance was deteriorated due to release of organic matters after $\mathrm{CaO}_{2}$ treatment at high dosages. The chemical composition of organic matters released would be characterized by EEM and HPSEC later.

In addition, Fig. 2 (b) showed that calcium ions in SEPS and LBEPS components reached the maximum of 64.836 and $35.074 \mathrm{mg} / \mathrm{L}$, respectively, when the dosage of $\mathrm{CaO}_{2}$ was $20 \mathrm{mg} / \mathrm{gTSS}$. However, the concentration of calcium ions in TB-EPS components rose steadily with an increase of $\mathrm{CaO}_{2}$ addition. With regard to Fig. 2 (c), after $\mathrm{CaO}_{2}$ addition of $20 \mathrm{mg} / \mathrm{gTSS}$, the concentration of calcium in sludge EPS reached the equilibrium while the rest of calcium in sludge pellet sharply increased. It suggested that the calcium ions generated by $\mathrm{CaO}_{2}$ mainly existed in sludge solid including LB-EPS, TB-EPS and pellet rather than SEPS.

\subsubsection{3-DEEM analysis}

3D-EEM method is widely used for characterization of natural organic matters in various water bodies with the advantages of high sensitivity and selectivity (Henderson et al., 2009). According to the report of Sheng and Yu (2006), fluorescence intensity of EEM could be used to measure EPS content as DOC content in samples was less than $10 \mathrm{mg} / \mathrm{L}$. It was investigated that three dimensional fluorescence spectrum is divided into five major regions, which are soluble microbial byproducts (tryptophan-like protein), aromatic protein I, aromatic protein II, humic acid and fulvic acid respectively (Chen et al., 2003). Fig. 3 showed that two fluorescent peaks in the SEPS, LB-EPS and TB-EPS: Peak A $\left(\lambda_{\text {ex } / \mathrm{em}}=280 / 335\right)$ - tryptophonlike proteins, Peak $B\left(\lambda_{\text {ex } / e m}=230 / 335\right)$ - aromatic proteins. It can be seen from Fig. 3 and Table 2, intensities of tryptophon-like and aromatic proteins in SEPS and LB-EPS components were obviously enhanced, while they were weakened in TB-EPS from 1580 to 792.8 to 1463 and 697.9 respectively. This may suggest that with $\mathrm{CaO}_{2}$ treatment, sludge flocs were effectively hydrolyzed and proteinlike substances were released. The results were in agreement with the analysis of DOC variation previously that protein-like organic matters in TB-EPS component transformed to LB-EPS and SEPS. As a result, the increase in concentrations of protein-like substances caused deterioration of sludge filtration dewatering performance (Zhang et al., 2015b).

\subsubsection{Molecular weight distribution analysis}

In MW measurement, it should be noted that carbohydrates contain no conjugated double bond, so the detection of them was only possible if they were present as part of molecular complexes such as glycoproteins and glycolipids (Lyko et al., 2007). Lyko et al. (2007) suggested that three main molar mass fractions can be distinguished: high MW organic compounds ( $>5000 \mathrm{Da}$ ) mainly composed of proteins and polysaccharides, mid-MW compounds (1000-5000 Da) and organic matter of low MW ( $<1000 \mathrm{Da})$. Bhatia et al. (2013) found that the MW of protein-like substances in EPS samples extracted from activated sludge was in a wide range of 1-600 kDa. The impact of $\mathrm{CaO}_{2}$ dosage and reaction time on $\mathrm{MW}$ distributions of SEPS fractions was presented in Fig. S2 of SI, and five MW peaks were observed in the SEPS fraction: $900 \mathrm{Da}$, 1500 Da, 2200 Da, 3000 Da and 50,000 Da. As can be seen in Fig. 4 (a), with the increase of $\mathrm{CaO}_{2}$ addition, intensity of each MW peak was enhanced except for the peak of $3000 \mathrm{Da}$. These results indicated that after $\mathrm{CaO}_{2}$ treatment, sludge flocs were effectively dissolved and released organic matters, which led to the increase of substances with various molecular weights, especially the mid and low MW compounds, which were always associated with proteinlike substances. In addition, Kiss et al. (2003) suggested the average molecular weight (AMW) of humic-like substances (HULIS) was in the range of 100-800 Da. Therefore, few humic compounds were released due to $\mathrm{CaO}_{2}$ addition, which could be confirmed by EEM spectrum without the signals of humic substances. In addition, Fig. 4 (b) demonstrated that the same five MW peaks were found in SEPS fraction after $\mathrm{CaO}_{2}$ addition with reaction time. This suggested that organic polymeric substances were effectively hydrolyzed to organic matters with lower MW.

\subsubsection{FTIR analysis}

As depicted in Fig. S3 of SI, varieties of characteristic peaks were found on IR spectrum of the control sample. Due to the complexity of EPS components and the presence of a large numbers of functional groups on the EPS, the exact characteristic absorption values are very difficult to determine in the IR spectrum. The broad absorption band between 3200 and $3400 \mathrm{~cm}^{-1}$ in the spectrum was assigned to the stretching vibrations of the $\mathrm{O}-\mathrm{H}$ groups of polymeric substances (Sheng et al., 2006; Tapia et al., 2009). The peaks from 2925 to 2935 and $2850-2860 \mathrm{~cm}^{-1}$ demonstrated the existence of aliphatic chains of polysaccharides, proteins and humic substances (Sheng et al., 2006; Wang et al., 2014). Chai et al. (2007) reported that the absorption of wavelengths between 2930 and $1650 \mathrm{~cm}^{-1}$ was related to humic acids (stretching vibrations of $\mathrm{C}=$ C). But, the IR identification of humic-like substances is very complicated because other organic groups also absorb in the same regions. The absorption band between 1635 and $1655 \mathrm{~cm}^{-1}$ was associated with the stretching vibrations of $\mathrm{C}=\mathrm{O}$ and $\mathrm{C}-\mathrm{N}$ of amide I of the protein (Bhatti and Hamid, 2014; Sun et al., 2012; Tapia et al., 2009). The band from 1445 to 1455 was due to the deformation of the $\mathrm{CH}_{3}$ and $\mathrm{CH}_{2}$ groups of amide III. The spectral band observed from 1035 to $1070 \mathrm{~cm}^{-1}$ (stretching vibration of $\mathrm{O}-\mathrm{H}$ groups) was a characteristic absorption region of polysaccharides of EPS (Omoike and Chorover, 2004; Sun et al., 2012; Tapia et al., 2009). Hence, the IR data confirmed the existence of protein and polysaccharides in the sludge samples. However, after $\mathrm{CaO}_{2}$ addition, the absorption intensities of peaks of 2852, 2926 and $1037 \mathrm{~cm}^{-1}$ was decreased, especially with the combined treatment of $\mathrm{CaO}_{2}$ and coagulants. This indicated that EPS components mainly composed by proteins and polysaccharides were oxidized and degraded after $\mathrm{CaO}_{2}$ oxidation, which was consistant with previous results.

\subsection{Kinetics of sludge solubilization by calcium peroxide conditioning}

\subsubsection{Kinetics of SEPS component}

As depicted in Fig. 5 (a), SEPS component significantly increased and it reached the equilibrium of $2.47 \mathrm{mgDOC} / \mathrm{gTSS}$ from 1.74 $\mathrm{mgDOC} / \mathrm{gTSS}$ when the reaction time was $60 \mathrm{~min}$. In addition, Fig. 5 (b) displayed that the EEM fluorescence intensities of tryptophonlike and aromatic protein were strengthened from 29.25 to 20.56 to 87.47 and 78.33 respectively after the time of $1 \mathrm{~h}$, which was similar to the change in SEPS. This may due to the sludge floc lysis and release of organic matters to SEPS component after $\mathrm{CaO}_{2}$ addition.

Kinetic modelings (see supporting information) were used to get further insights into the kinetic variation in EPS characteristics 
SEPS
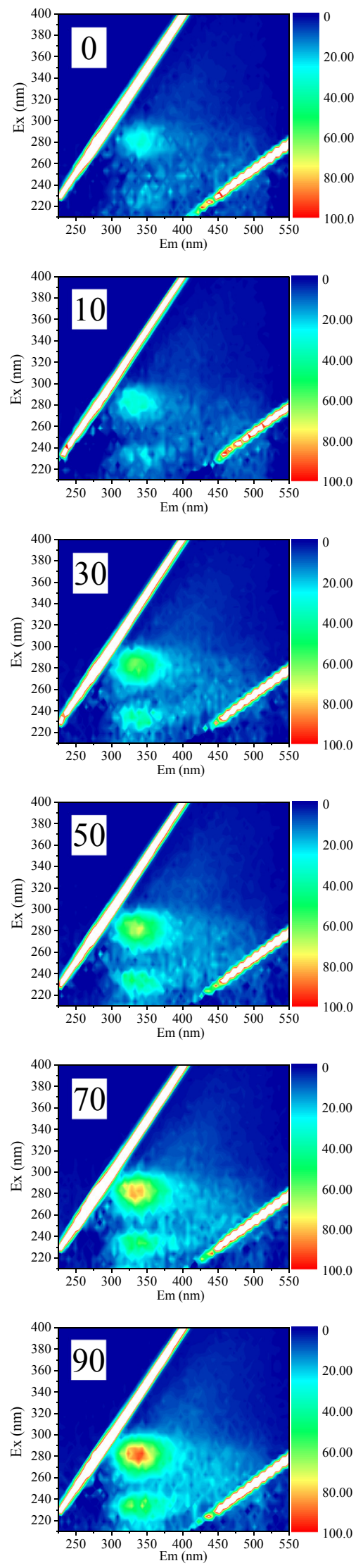

LB-EPS
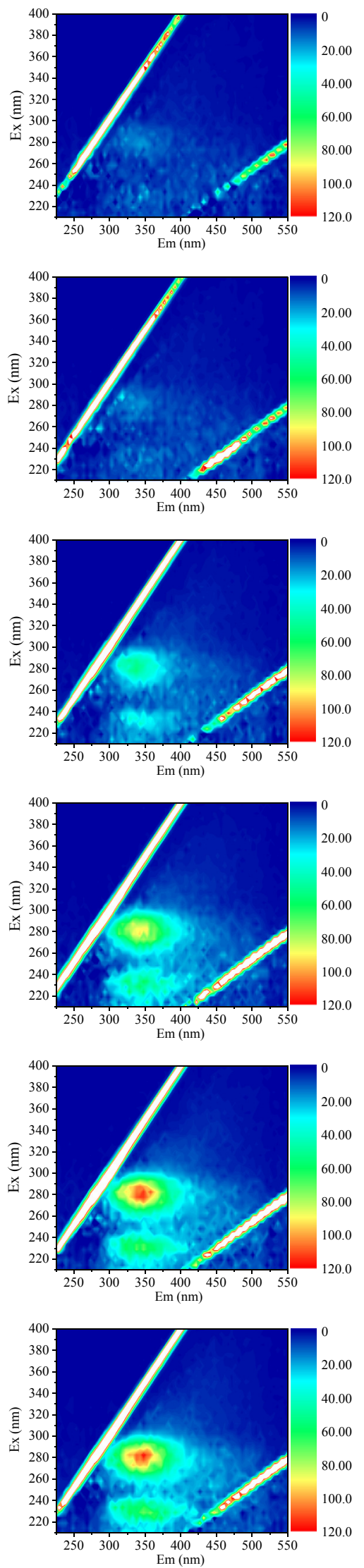

TB-EPS
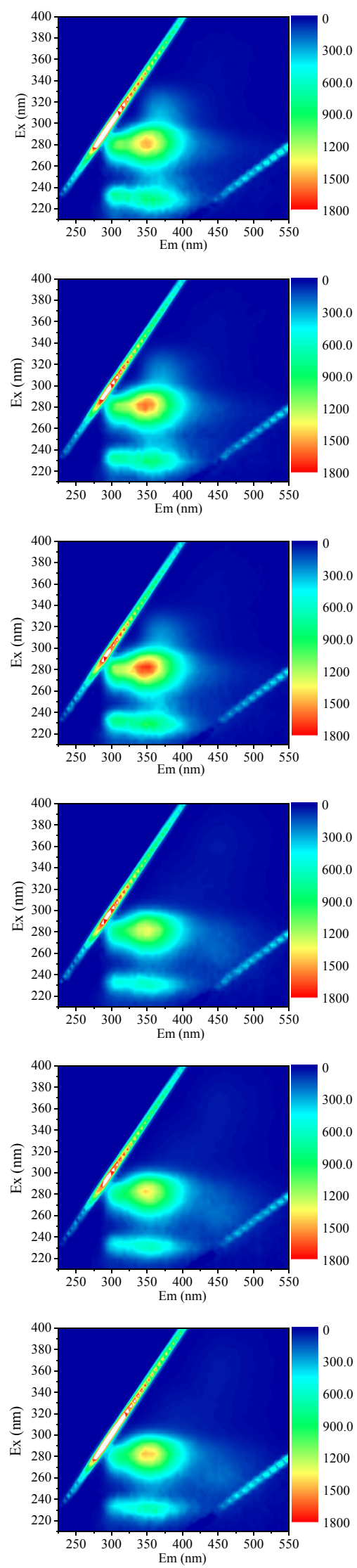

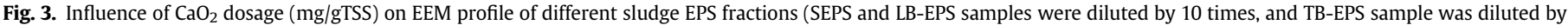
50 times). 
Table 2

Influence of $\mathrm{CaO}_{2}$ dosage on intensities of fluorescent peaks in different EPS fractions.

\begin{tabular}{|c|c|c|c|c|c|c|}
\hline \multirow[t]{2}{*}{$\mathrm{Ca}_{2} \mathrm{O}$ dosage (mg/gTSS) } & \multicolumn{2}{|l|}{ SEPS } & \multicolumn{2}{|l|}{ LB-EPS } & \multicolumn{2}{|l|}{ TB-EPS } \\
\hline & Tryptophan protein & Aromatic protein & Tryptophan protein & Aromatic protein & Tryptophan protein & Aromatic protein \\
\hline$\lambda(\mathrm{Ex} / \mathrm{Em})$ & $280 / 335$ & $230 / 335$ & $280 / 335$ & $230 / 335$ & $280 / 335$ & $230 / 335$ \\
\hline 0 & 34.56 & 13.21 & 19.53 & 19.45 & 1580 & 792.8 \\
\hline 10 & 36.98 & 29.96 & 34.98 & 21.58 & 1594 & 836.4 \\
\hline 20 & 51.91 & 51.08 & 44.52 & 32.78 & 1629 & 723.2 \\
\hline 30 & 61.66 & 47.85 & 54.45 & 41.62 & 1721 & 947.0 \\
\hline 50 & 72.37 & 54.90 & 93.53 & 61.17 & 1344 & 626.6 \\
\hline 70 & 82.94 & 57.89 & 114.0 & 71.10 & 1444 & 665.3 \\
\hline 90 & 92.94 & 71.24 & 120.4 & 74.26 & 1463 & 697.9 \\
\hline
\end{tabular}

*SEPS and LB-EPS samples were diluted by 10 times, and TB-EPS sample was diluted by 50 times.

under calcium peroxide oxidation. The fitting results were given in Fig. S4 of SI. According to correlation coefficient $\left(\mathrm{R}^{2}\right)$, it was clear that the variation in SEPS component could be fitted well with pseudo-zero order kinetic equation due to its $\mathrm{R}^{2}$ of 0.926 , and the reaction rate was $0.252 \mathrm{mg} /(\mathrm{L} \cdot \mathrm{min})$, and sludge solubilization rate $0.0148 \mathrm{mg} /(\mathrm{gTSS} \cdot \mathrm{min})$. Thus, it suggested that EPS solubilization rate under $\mathrm{CaO}_{2}$ oxidation was not affected by sludge concentration. Sahinkaya et al. (2015) also found that the process of sludge hydrolysis by Fenton oxidation could be divided into two steps which were fast and slow oxidation, meanwhile the rapid hydrolysis followed the zero order kinetic model.

\subsubsection{Kinetics of calcium ion}

The change in concentration of calcium ion with reaction time in SEPS can be found in Fig. 6. It showed that the concentration of $\mathrm{Ca}^{2+}$ carried on rising obviously within the reaction time of $1 \mathrm{~h}$. Then it
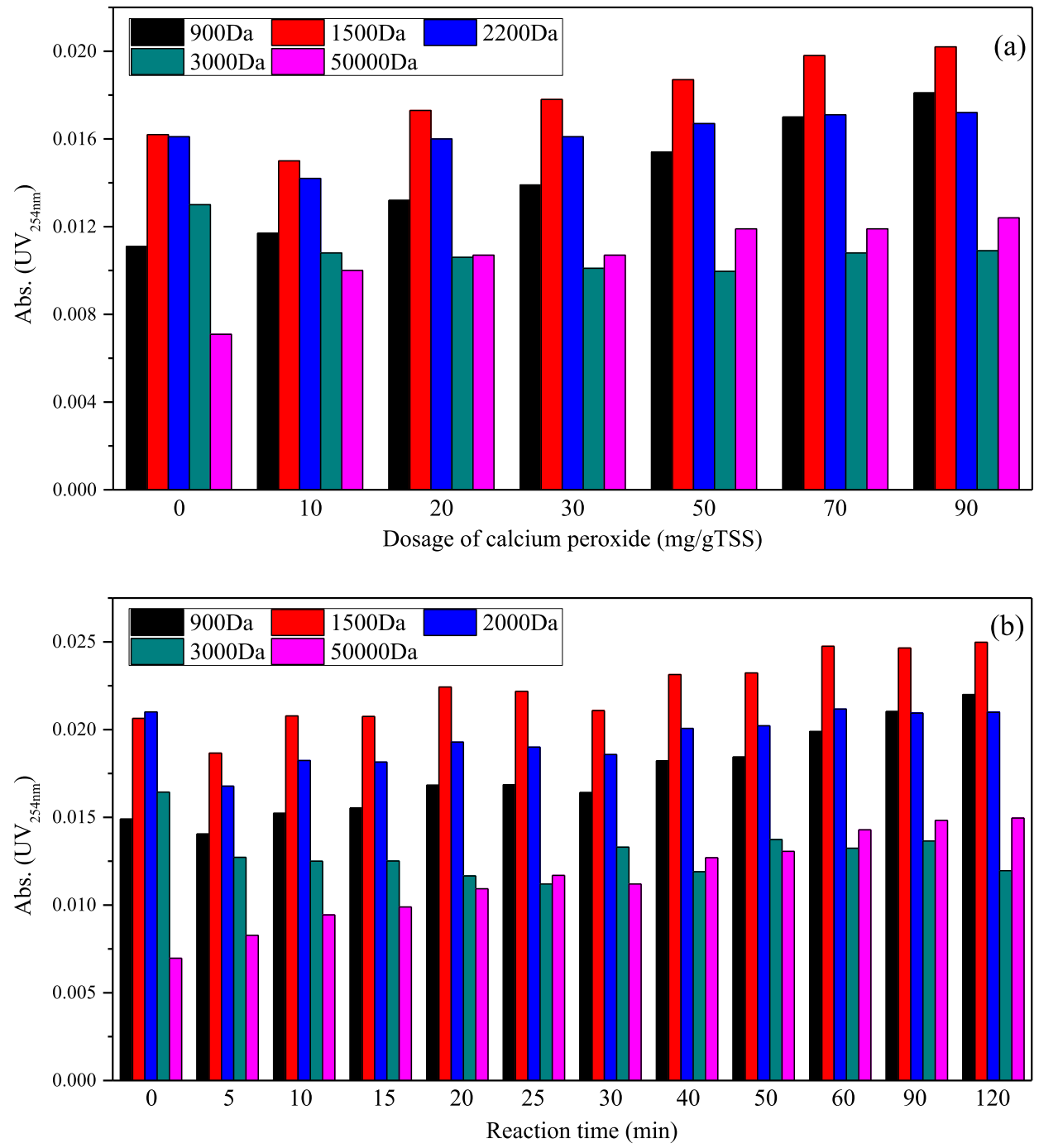

Fig. 4. Effects of $\mathrm{CaO}_{2}$ oxidation on peak intensities of MW distribution in SEPS: (a) dosage; (b) reaction time (Samples were diluted by 10 times). 

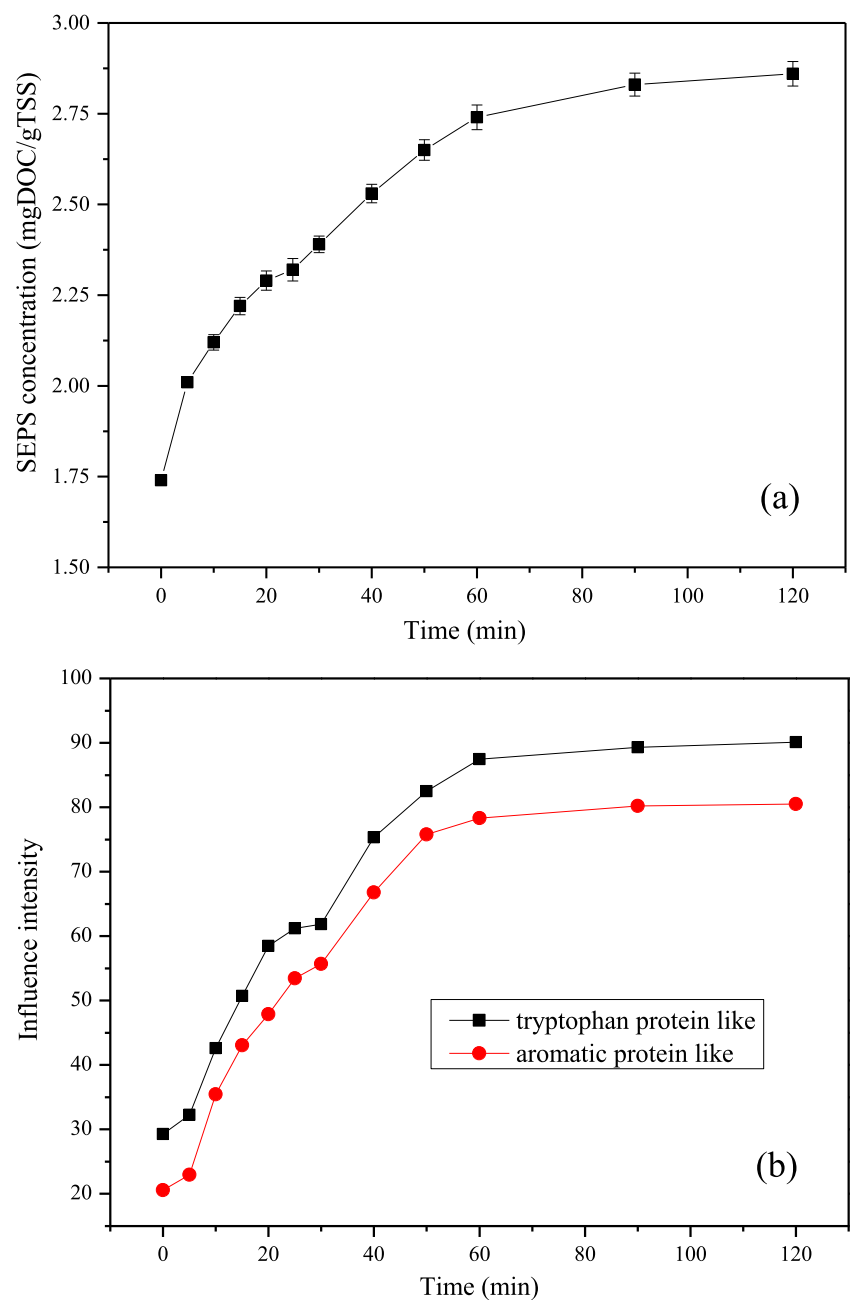

Fig. 5. Variation in SEPS component after $\mathrm{CaO}_{2}$ addition with reaction time: (a) SEPS content; (b) Fluorescent intensities in EEM contours (Samples for EEM were diluted by 10 times).

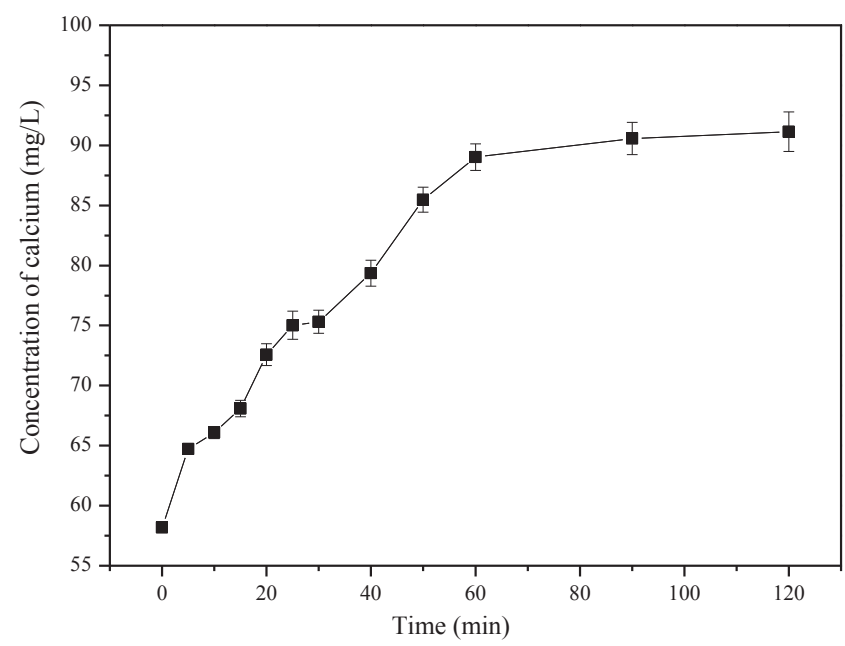

Fig. 6. Variation of $\mathrm{Ca}^{2+}$ in SEPS with reaction time.

reached the equilibrium of $89.018 \mathrm{mg} / \mathrm{L}$ from $58.179 \mathrm{mg} / \mathrm{L}$. In addition, the procedure of $\mathrm{CaO}_{2}$ solubilization was fitted well with zero order kinetic model (see in Fig. S5 of SI), which was consistent with the kinetics of SEPS component. And its $\mathrm{R}^{2}$ and reaction rate were respectively 0.974 and $0.481 \mathrm{mg} /(\mathrm{L} \cdot \mathrm{min})$.

Reaction Equations (7) and (8) can be used to illustrate the process of $\mathrm{CaO}_{2}$ solubilization (Khodaveisi et al., 2011):

$\mathrm{H}_{2} \mathrm{O} \leftrightarrow \mathrm{H}^{+}+\mathrm{OH}^{-}$

$\mathrm{CaO}_{2}+2 \mathrm{H}^{+} \leftrightarrow \mathrm{Ca}^{2+}+\mathrm{H}_{2} \mathrm{O}_{2}$

The sludge hydrolysis with $\mathrm{CaO}_{2}$ addition was due to the oxidation of hydrogen peroxide generated by $\mathrm{CaO}_{2}$ dissolution rather than $\mathrm{CaO}_{2}$ itself. Hence, solubilization of sludge flocs was the rate-limiting reaction of $\mathrm{CaO}_{2}$ dissolution which was confirmed by the lower reaction rate of $0.252 \mathrm{mg} /(\mathrm{L} \cdot \mathrm{min})$. The change in SEPS component followed the pseudo-zero order kinetics. However, with hydrogen ions consumption and $\mathrm{pH}$ rising, the $\mathrm{CaO}_{2}$ dissolution and hydrogen peroxide generation were gradually suppressed. Therefore, the concentration of $\mathrm{Ca}^{2+}$ trended to be stable after $1 \mathrm{~h}$ reaction and the variation in SEPS reached the equilibrium at the same times. Sahinkaya et al. (2015) suggested that the reaction rate of sludge hydrolysis were up to 50.10 and $33.95 \mathrm{mg} /(\mathrm{L} \cdot \mathrm{min})$ by using conventional Fenton and Fenton type process respectively. Northup and Cassidy (2008) reported that $\mathrm{CaO}_{2}$ was able to maintain oxidation reactions over a long period of time since it was dissolved slowly in water. By contrast, the sludge conditioning by $\mathrm{CaO}_{2}$ oxidation lasted a long time but it was safe due to its lower reaction rate.

\subsection{Sludge conditioning with calcium peroxide pre-oxidation and chemical re-flocculation}

\subsubsection{Sludge dewatering performance}

It revealed that sludge condition with inorganic coagulants might be divided into two steps. Initially, sludge particles rapidly aggregated into large flocs due to bridging and charge neutralization, hydrolysis products of inorganic coagulants could neutralize the surface charge of the particles and the suspension would be destabilized (Higgins and Novak, 1997b); And then the floc size decreased gradually owing to water stripping from aggregates caused by double electric layer compression as reaction time was going on. Finally, when the balance between the rate of aggregation and the rate of breakage for a given shear condition was reached, the size of flocs reached a steady plateau (Biggs et al., 2001). As depicted in Fig. 7, after $\mathrm{CaO}_{2}$ addition with $\mathrm{PACl}, \mathrm{FeCl}_{3}$ and PAM conditioning, the sludge SRF decreased significantly from initial $3.46 \times 10^{13} \mathrm{~m} / \mathrm{kg}$ to $3.55 \times 10^{12}, 4.36 \times 10^{12}$ and $2.75 \times 10^{11} \mathrm{~m} / \mathrm{kg}$, respectively, which were lower than control tests accordingly. It should be noted that the sludge cake moisture content with $\mathrm{CaO}_{2}$ treatment decreased much more than control experiments, which dropped from $91.83 \%$ to $79.46,79.27$ and $81.32 \%$, respectively. This observation revealed that combination with $\mathrm{CaO}_{2}$ pre-oxidation and chemical flocculation was high-efficiency in sludge dewatering performance, especially cake moisture content reduction. This may due to the conversion from bound water to free water which was easy to remove in sludge flocs by using $\mathrm{CaO}_{2}$ oxidation (Neyens et al., 2004). In addition, with regard to re-flocculation, inorganic coagulants of $\mathrm{PACl}$ and $\mathrm{FeCl}_{3}$ were more effective in cake moisture content reduction than PAM, which resulted in the reduction to $80 \%$ below. It was reported that density of sludge flocs would be enhanced by $\mathrm{PACl}$ and $\mathrm{FeCl}_{3}$ with their high charge density and the free water in sludge EPS could be efficiently removed under compression of double electric layer (Niu et al., 2013). In addition, the hydrolytic products of $\mathrm{Al}$ and Fe salts can act as skeleton builders to enhance the floc strength and reduce the sludge compressibility. 

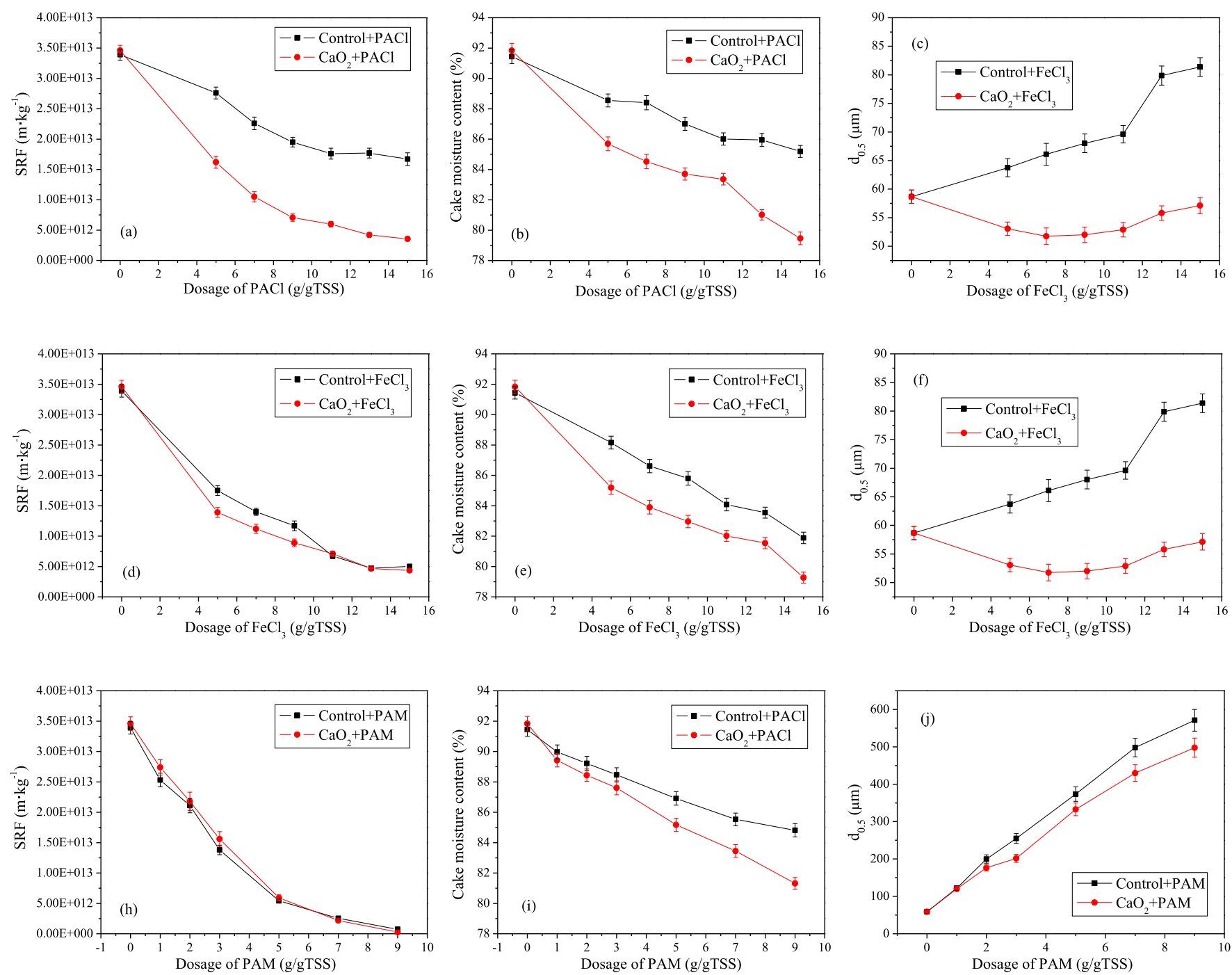

Fig. 7. Effects of chemical re-flocculation with different coagulants on sludge dewatering performance and floc size distribution: (a) (b) (c) $\mathrm{PACl}$; (d) (e) (f) $\mathrm{FeCl}$; (h) (i) (j) PAM.

\subsubsection{Morphological properties of sludge flocs}

3.4.2.1. Sludge floc size. After flocculation with $\mathrm{PACl}$ and $\mathrm{FeCl}_{3}$ (see Fig. 7 (c) and (f)), original sludge floc size obviously increased from $58.68 \mu \mathrm{m}$ to 231.65 and $81.37 \mu \mathrm{m}$ respectively when the dosages were $15 \mathrm{~g} / \mathrm{gTSS}$. However, there was no noticeable change in floc size when sludge was conditioned with $\mathrm{CaO}_{2}$ pre-oxidation. In addition, as depicted in Fig. 7 (j), both raw and pre-treated sludge had a significant increase in floc size from $58.68 \mu \mathrm{m}$ to 570.98 and $497.82 \mu \mathrm{m}$ after PAM addition. Firstly, it should be noted that coagulated sludge floc size was slightly reduced after oxidative pretreatment. It was very likely that organic matters with high MW in sludge EPS was converted into smaller organic compounds, and alleviated the electrostatic and hydrophobic interactions between hydrolyzed products of coagulants and EPS components (Lee and Liu, 2001). It was obvious that flocs formed by PACl coagulation were larger than that conditioned with $\mathrm{FeCl}_{3}$. It was likely that $\mathrm{Al}_{\mathrm{b}}$ and $\mathrm{Al}_{\mathrm{C}}$ accounted for $60-80 \%$ of total $\mathrm{Al}$, while the hydrolytic products of $\mathrm{Fe}^{3+}$ existed in the form of iron hydroxides (Niu et al., 2013). Therefore, the binding sites of PACl are much abundant than that of iron hydroxides, hence the larger flocs were produced. It is interesting to note that the largest flocs with the poorest dewatering property were produced by using PAM flocculation after $\mathrm{CaO}_{2}$ pre-oxidation. As depicted in Fig. $\mathrm{S} 6$ of $\mathrm{SI}$, this could be suggested that organic polymeric flocculants (eg. PAM) were able to generate larger and but loose flocs with good settling property through bridging and sweeping compared to metal salt coagulants (Wong et al., 2006).

3.4.2.2. FE-SEM analysis. The sludge floc morphology under FE-SEM can be seen in Fig. 8. The raw sludge floc had a relative smooth surface (see Fig. 8 (a)) while after $\mathrm{CaO}_{2}$ oxidation, the structure of flocs demonstrated the characteristics including loose and complexity of pore distribution. And more $\mathrm{CaO}_{2}$ was dosed, the higher degree of fragmentation on sludge floc surface can be seen (see Fig. 8 (b) and (c)). It is not difficult to demonstrate that sludge flocs were significantly solubilized with $\mathrm{CaO}_{2}$ pre-treatment. In addition, sludge flocs were obviously aggregated after chemical reflocculation with coagulants. In addition, it was interesting to note that pore structure of sludge flocs treated with $\mathrm{CaO}_{2}$ oxidation were more plentiful and which might provide more channels for water release (see in Fig. 8 (b) and (c)). Furthermore, the flocs conditioned with inorganic coagulants (Al and Fe salts) had bigger fragmentations and more abundant porous structure than conditioned with PAM, indicating that more stronger flocs formed in inorganic coagulants flocculation seen in Fig. 8 (d), (e) and (f). This observation was in agreement with the change in floc size and $D_{F}$ (Niu et al., 2013). 

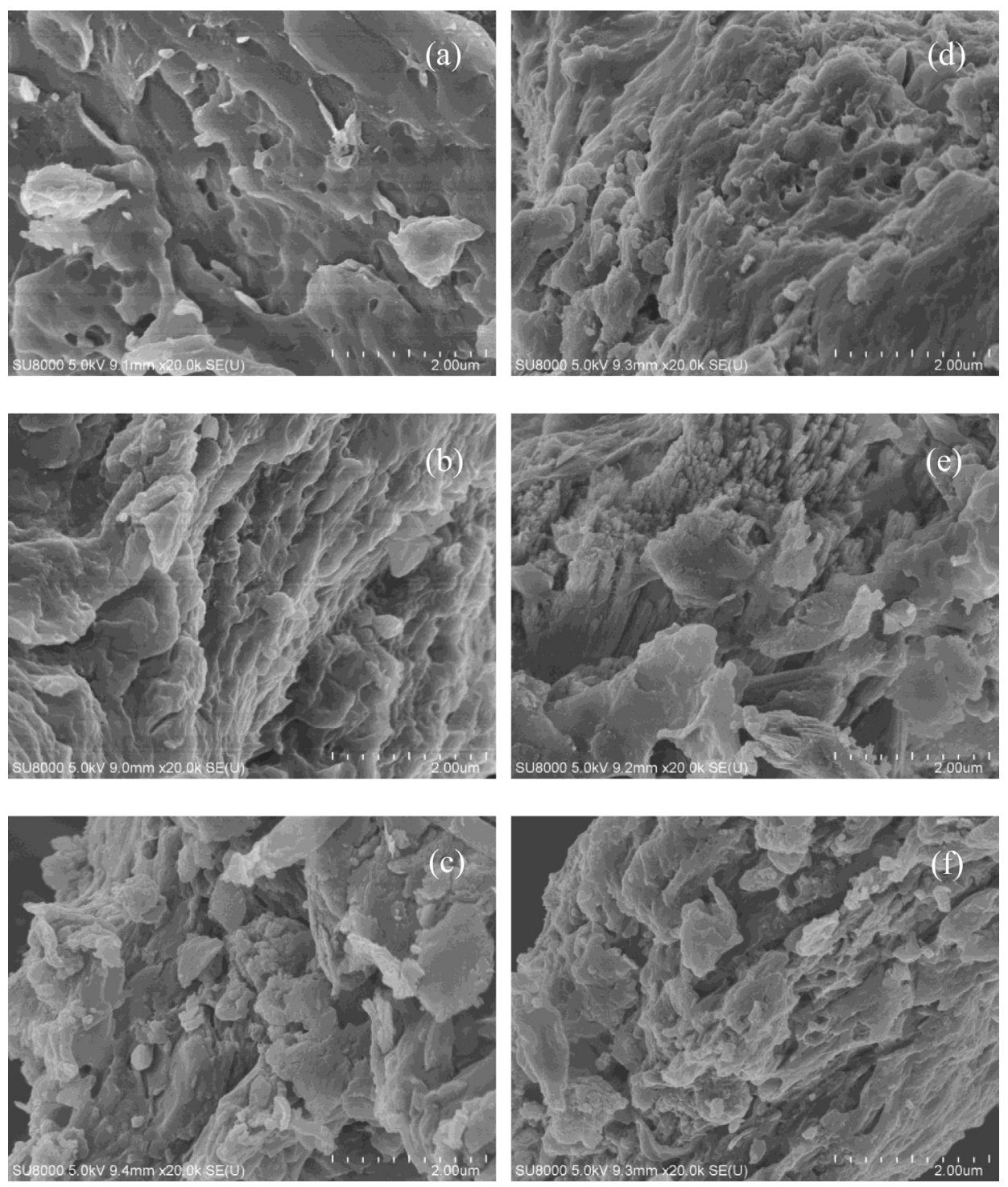

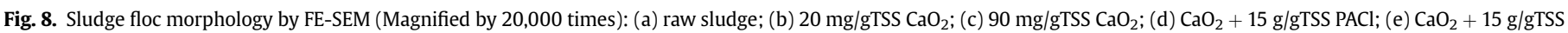
$\mathrm{FeCl}_{3}$; (f) $\mathrm{CaO}_{2}+15 \mathrm{~g} / \mathrm{gTSS}$ PAM.

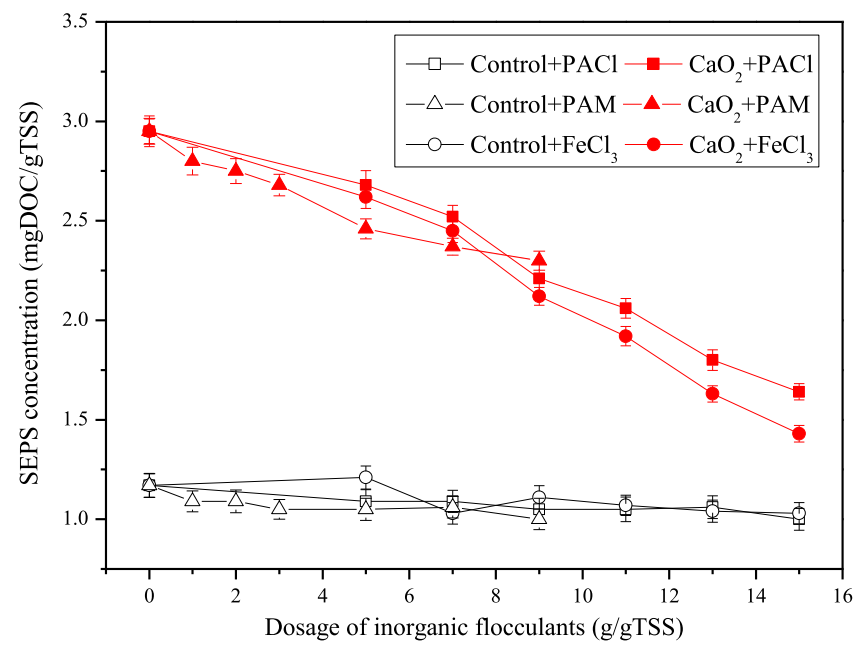

Fig. 9. Variation in SEPS concentration after chemical re-flocculation with different coagulants.

\subsubsection{Change in EPS properties under combined conditioning}

Fig. 9 presented that SEPS content was decrease under chemical flocculation, this observation was more noticeable after $\mathrm{CaO}_{2}$ addition. The SEPS concentration was reduced from $2.95 \mathrm{mgDOC} /$ gTSS to $1.64,1.43$ and $2.30 \mathrm{mgDOC} / \mathrm{gTSS}$ with $\mathrm{PACl}, \mathrm{Fe}^{3+}$ and PAM addition respectively, revealing that $\mathrm{FeCl}_{3}$ was more effective in removing organic matters in sludge. It was suggested that ferric ions exhibited higher affinity to protein-like substances (Yu et al., 2008). In addition, according to our previous report, protein like substances in SEPS fraction were found to be the main influencing factor of sludge filtration dewatering performance (Zhang et al., 2015c). It is obvious that $\mathrm{FeCl}_{3}$ conditioning performed better in removal of SEPS due to strong binding strength between ferric ions and protein-like substances, which contributed to improvement of sludge filtration behavior. In addition, the change of characteristic absorption curve after coagulants addition can be attributed to formation of organic-metal complexes, which can also be reflected by FTIR spectra in Fig. S3 of SI. 


\section{Conclusion}

This study attempted to use $\mathrm{CaO}_{2}$ pre-oxidation and chemical re-flocculation to improve sludge dewatering performance.

- Waste activated sludge dewaterability was relatively enhanced by using optimal $\mathrm{CaO}_{2}$ pre-oxidation and the optimum dosage was $20 \mathrm{mg} / \mathrm{gTSS}$. However, sludge filtration performance was worse due to the absence of oxidation with lower dosage and the release of protein-like substances at higher dosage.

- Sludge floc was effectively broken and its structure became much looser after $\mathrm{CaO}_{2}$ addition. Meanwhile, protein-like substances in TB-EPS component gradually converted into LB-EPS and SEPS.

- The variation in SEPS component can be fitted well with pseudo-zero-order kinetic model. sludge solubilization rate $0.0148 \mathrm{mg} /(\mathrm{gTSS} \cdot \mathrm{min})$ under $\mathrm{CaO}_{2}$ treatment.

- Sludge floc structure was reconstructed and sludge dewaterability was significantly enhanced after chemical reflocculation by using coagulants ( $\mathrm{PACl}, \mathrm{FeCl}_{3}$ and $\mathrm{PAM}$ ). The sludge cake moisture content could be decreased to $80 \mathrm{wt} \%$ below under addition of inorganic coagulants of $\mathrm{PACl}$ and $\mathrm{FeCl}_{3}$ due to their higher charge neutralization and skeleton builders of hydrolysis products.

\section{Acknowledgments}

This work was supported by the National Nature Science Foundation of China (No. 21277130, 51478445, 51338010 and 21477118), Chinese Universities Scientific Fund (CUG160824) and China Postdoctoral Science Foundation (2016M590733).

\section{Appendix A. Supplementary data}

Supplementary data related to this article can be found at http:// dx.doi.org/10.1016/j.watres.2016.07.018.

\section{References}

APHA, A., 1998. WEF. Standard Methods for the Examination of Water and Wastewater, twentieth ed. American Public Health Association, American Water Work Association, Water Environment Federation, Washington DC, p. 252.

Beauchesne, I., Ben Cheikh, R., Mercier, G., Blais, J.F., Ouarda, T., 2007. Chemical treatment of sludge: in-depth study on toxic metal removal efficiency, dewatering ability and fertilizing property preservation. Water Res. 41 (9), 2028-2038.

Bhatia, D., Bourven, I. Simon, S., Bordas, F., van Hullebusch, E.D., Rossano, S., Lens, P.N.L., Guibaud, G., 2013. Fluorescence detection to determine proteins and humic-like substances fingerprints of exopolymeric substances (EPS) from biological sludges performed by size exclusion chromatography (SEC). Bioresour. Technol. 131, 159-165.

Bhatti, H.N., Hamid, S., 2014. Removal of uranium(VI) from aqueous solutions using Eucalyptus citriodora distillation sludge. Int. J. Environ. Sci. Technol. 11 (3), $813-822$.

Biggs, C.A., Ford, A.M., Lant, P.A., 2001. Activated sludge flocculation: direct determination of the effect of calcium ions. Water Sci. Technol. 43 (11), 75-82.

Chai, X.L., Shimaoka, T., Cao, X.Y., Guo, Q., Zhao, Y.C., 2007. Spectroscopic studies of the progress of humification processes in humic substances extracted from refuse in a landfill. Chemosphere 69 (9), 1446-1453.

Chen, W., Westerhoff, P., Leenheer, J.A., Booksh, K., 2003. Fluorescence excitation emission matrix regional integration to quantify spectra for dissolved organic matter. Environ. Sci. Technol. 37 (24), 5701-5710.

Chen, Z., Zhang, W.J., Wang, D.S., Ma, T., Bai, R.Y., 2015. Enhancement of activated sludge dewatering performance by combined composite enzymatic lysis and chemical re-flocculation with inorganic coagulants: Kinetics of enzymatic reaction and re-flocculation morphology. Water Res. 83, 367-376.

Chow, C.W.K., Fabris, R., van Leeuwen, J., Wang, D.S., Drikas, M., 2008. Assessing natural organic matter treatability using high performance size exclusion chromatography. Environ. Sci. Technol. 42 (17), 6683-6689.

Eriksson, L., Alm, B., 1993. Characterization of activated-sludge and conditioning with cationic polyelectrolytes. Water. Sci. Technol. 28 (1), 203-212.
Henderson, R.K., Baker, A., Murphy, K.R., Hamblya, A., Stuetz, R.M., Khan, S.J., 2009. Fluorescence as a potential monitoring tool for recycled water systems: a review. Water Res. 43 (4), 863-881.

Higgins, M.J., Novak, J.T., 1997a. Characterization of exocellular protein and its role in bioflocculation. J. Environ. Eng-Asce 123 (5), 479-485.

Higgins, M.J., Novak, J.T., 1997b. Dewatering and settling of activated sludges: the case for using cation analysis. Water Environ. Res. 69 (2), 225-232.

Houghton, J.I., Quarmby, J., Stephenson, T., 2001. Municipal wastewater sludge dewaterability and the presence of microbial extracellular polymer. Water Sci. Technol. 44 (2-3), 373-379.

Hung, W.T., Chang, I.L., Lin, W.W., Lee, D.J., 1996. Unidirectional freezing of waste activated sludges: effects of freezing speed. Environ. Sci. Technol. 30 (7), 2391-2396.

Khodaveisi, J., Banejad, H., Afkhami, A., Olyaie, E., Lashgari, S., Dashti, R., 2011. Synthesis of calcium peroxide nanoparticles as an innovative reagent for in situ chemical oxidation. J. Hazard. Mater 192 (3), 1437-1440.

Kim, Y.K., Bae, J.H., Oh, B.K., Lee, W.H., Choi, J.W., 2002. Enhancement of proteolytic enzyme activity excreted from Bacillus stearothermophilus for a thermophilic aerobic digestion process. Bioresour. Technol. 82 (2), 157-164.

Kiss, G., Tombacz, E., Varga, B., Alsberg, T., Persson, L., 2003. Estimation of the average molecular weight of humic-like substances isolated from fine atmospheric aerosol. Atmos. Environ. 37 (27), 3783-3794.

Lee, C.H., Liu, J.C., 2001. Sludge dewaterability and floc structure in dual polymer conditioning. Adv. Environ. Res. 5 (2), 129-136.

Li, X.Y., Yang, S.F., 2007. Influence of loosely bound extracellular polymeric substances (EPS) on the flocculation, sedimentation and dewaterability of activated sludge. Water Res. 41 (5), 1022-1030.

Liu, H., Fang, H.H.P., 2002. Extraction of extracellular polymeric substances (EPS) of sludges. J. Biotechnol. 95 (3), 249-256.

Liu, H., Yang, J.K., Zhu, N.R., Zhang, H., Li, Y., He, S., Yang, C.Z., Yao, H., 2013 A comprehensive insight into the combined effects of Fenton's reagent and skeleton builders on sludge deep dewatering performance. J. Hazard. Mater 258, 144-150.

Low, E.W., Chase, H.A., Milner, M.G., Curtis, T.P., 2000. Uncoupling of metabolism to reduce biomass production in the activated sludge process. Water Res. 34 (12), 3204-3212.

Lyko, S., Al-Halbouni, D., Wintgens, T., Janot, A., Hollender, J., Dott, W., Melin, T. 2007. Polymeric compounds in activated sludge supernatant characterisation and retention mechanisms at a full-scale municipal membrane bioreactor. Water Res. 41 (17), 3894-3902.

Lyko, S., Wintgens, T., Al-Halbouni, D., Baumgarten, S., Tacke, D., Drensla, K. Janot, A., Dott, W., Pinnekamp, J., Melin, T., 2008. Long-term monitoring of a full-scale municipal membrane bioreactor - characterisation of foulants and operational performance. J. Membr. Sci. 317 (1-2), 78-87.

Ma, Y., Zhang, B.T., Zhao, L.X., Guo, G.S., Lin, J.M., 2007. Study on the generation mechanism of reactive oxygen species on calcium peroxide by chemiluminescence and UV-visible spectra. Lumin 22 (6), 575-580.

Mikkelsen, L.H., Keiding, K., 2002. Physico-chemical characteristics of full scale sewage sludges with implications to dewatering. Water Res. 36 (10), 2451-2462.

Murthy, S.N., Novak, J.T., 1999. Factors affecting floc properties during aerobic digestion: implications for dewatering. Water Environ. Res. 71 (2), 197-202.

Ndjou'ou, A.C., Cassidy, D., 2006. Surfactant production accompanying the modified Fenton oxidation of hydrocarbons in soil. Chemosphere 65 (9), 1610-1615.

Neyens, E., Baeyens, J., 2003. A review of classic Fenton's peroxidation as an advanced oxidation technique. J. Hazard. Mater 98 (1-3), 33-50.

Neyens, E., Baeyens, J., Dewil, R., De heyder, B., 2004. Advanced sludge treatment affects extracellular polymeric substances to improve activated sludge dewatering. J. Hazard. Mater 106 (2-3), 83-92.

Niu, M.Q., Zhang, W.J., Wang, D.S., Chen, Y., Chen, R.L., 2013. Correlation of physicochemical properties and sludge dewaterability under chemical conditioning using inorganic coagulants. Bioresour. Technol. 144, 337-343.

Northup, A., Cassidy, D., 2008. Calcium peroxide (CaO2)for use in modified Fenton chemistry. J. Hazard. Mater 152 (3), 1164-1170.

Omoike, A., Chorover, J., 2004. Spectroscopic study of extracellular polymeric substances from Bacillus subtilis: aqueous chemistry and adsorption effects. Biomacromolecules 5 (4), 1219-1230.

Poxon, T.L., Darby, J.L., 1997. Extracellular polyanions in digested sludge: measurement and relationship to sludge dewaterability. Water Res. 31 (4), 749-758.

Qian, Y.J., Zhou, X.F., Zhang, Y.L., Zhang, W.X., Chen, J.B., 2013. Performance and properties of nanoscale calcium peroxide for toluene removal. Chemosphere 91 (5), 717-723.

Ramesh, A., Lee, D.J., Hong, S.G., 2006. Soluble microbial products (SMP) and soluble extracellular polymeric substances (EPS) from wastewater sludge. Appl. Microbiol. Biot. 73 (1), 219-225.

Raynaud, M., Vaxelaire, J., Olivier, J., Dieude-Fauvel, E., Baudez, J.C., 2012. Compression dewatering of municipal activated sludge: effects of salt and $\mathrm{pH}$. Water Res. 46 (14), 4448-4456.

Sahinkaya, S., Kalipci, E., Aras, S., 2015. Disintegration of waste activated sludge by different applications of Fenton process. Process Saf. Environ 93, 274-281.

Sheng, G.P., Yu, H.Q., 2006. Characterization of extracellular polymeric substances of aerobic and anaerobic sludge using three-dimensional excitation and emission matrix fluorescence spectroscopy. Water Res. 40 (6), 1233-1239.

Sheng, G.P., Yu, H.Q., Wang, C.M., 2006. FTIR-spectral analysis of two photosynthetic H-2-producing strains and their extracellular polymeric substances. Appl. 
Microbiol. Biot. 73 (1), 204-210.

Sun, M., Li, W.W., Mu, Z.X., Wang, H.L., Yu, H.Q., Li, Y.Y., Harada, H., 2012. Selection of effective methods for extracting extracellular polymeric substances (EPSs) from Bacillus megaterium TF10. Sep. Purif. Technol 95, 216-221.

Tapia, J.M., Munoz, J.A., Gonzalez, F., Blazquez, M.L., Malki, M., Ballester, A., 2009. Extraction of extracellular polymeric substances from the acidophilic bacterium Acidiphilium 3.2Sup(5). Water Sci. Technol. 59 (10), 1959-1967.

Thomas, L., Jungschaffer, G., Sprossler, B., 1993. Improved sludge dewatering by enzymatic treatment. Water Sci. Technol 28 (1), 189-192.

Tokumura, M., Sekine, M., Yoshinari, M., Znad, H.T., Kawase, Y., 2007. Photo-Fenton process for excess sludge disintegration. Process Biochem. 42 (4), 627-633.

Vaxelaire, J., Cezac, P., 2004. Moisture distribution in activated sludges: a review. Water Res. 38 (9), 2215-2230.

Wang, D.S., Xing, L.N., Xie, J.K., Chow, C.W.K., Xu, Z.Z., Zhao, Y.M., Drikas, M., 2010 Application of advanced characterization techniques to assess DOM treatability of micro-polluted and un-polluted drinking source waters in China. Chemosphere 81 (1), 39-45.

Wang, Z.C., Gao, M.C., Wang, S., Xin, Y.J., Ma, D., She, Z.L., Wang, Z., Chang, Q.B. Ren, Y., 2014. Effect of hexavalent chromium on extracellular polymeric substances of granular sludge from an aerobic granular sequencing batch reactor Chem. Eng. J. 251, 165-174.

Wei, J.C., Gao, B.Y., Yue, Q.Y., Wang, Y., Li, W.W., Zhu, X.B., 2009. Comparison of coagulation behavior and floc structure characteristic of different polyferriccationic polymer dual-coagulants in humic acid solution. Water Res. 43 (3) 724-732.

Wei, Y.S., Van Houten, R.T., Borger, A.R., Eikelboom, D.H., Fan, Y.B., 2003. Comparison performances of membrane bioreactor and conventional activated sludge processes on sludge reduction induced by Oligochaete. Environ. Sci. Technol. 37 (14), 3171-3180.

Wong, S.S., Teng, T.T., Ahmad, A.L., Zuhairi, A., Najafpour, G., 2006. Treatment of pulp and paper mill wastewater by polyacrylamide (PAM) in polymer induced flocculation. J. Hazard. Mater 135 (1-3), 378-388.

Wu, H.Y., Gao, J.Y., Yang, D.H., Zhou, Q., Liu, W., 2010. Alkaline fermentation of primary sludge for short-chain fatty acids accumulation and mechanism. Chem. Eng. J. 160 (1), 1-7.

Yu, G.H., He, P.J., Shao, L.M., He, P.P., 2008. Stratification structure of sludge flocs with implications to dewaterability. Environ. Sci. Technol. 42 (21), 7944-7949.

Zhang, A., Wang, J., Li, Y.M., 2015a. Performance of calcium peroxide for removal of endocrine-disrupting compounds in waste activated sludge and promotion of sludge solubilization. Water Res. 71, 125-139.

Zhang, W.J., Peng, S.W., Xiao, P., He, J., Yang, P., Xu, S.W., Wang, D.S., 2015b. Understanding the evolution of stratified extracellular polymeric substances in full-scale activated sludges in relation to dewaterability. Rsc Adv. 5 (2), $1282-1294$.

Zhang, W.J., Xiao, P., Liu, Y.Y., Xu, S.W., Xiao, F., Wang, D.S., Chow, C.W.K., 2014. Understanding the impact of chemical conditioning with inorganic polymer flocculants on soluble extracellular polymeric substances in relation to the sludge dewaterability. Sep. Purif. Technol. 132, 430-437.

Zhang, W.J., Yang, P., Xiao, P., Xu, S.W., Liu, Y.Y., Liu, F., Wang, D.S., 2015c. Dynamic variation in physicochemical properties of activated sludge floc from different WWTPs and its influence on sludge dewaterability and settleability. Colloid Surf. A 467, 124-134.

Zhu, J., Peng, Y., Li, X., Su, G., Wang, S., 2013. Change and mechanism of sludge dewaterability during alkaline fermentation. CIESC J. 64 (11), 4210-4215. 